\title{
The Urgency Principle "Adati Hula Hula Sareati, Sareati Hula Hula to Kitabullah" In Gorontalo in the Legal Protection Toward Women as the Victims of Violence
}

\author{
Lusiana M Tijow ${ }^{1}$ Hoiruddin Hasibuan ${ }^{2}$ \\ 1.Faculty Of Law, The State University of Gorontalo \\ 2.Faculty Of Law, Wisnu Wardhana University
}

\begin{abstract}
Gorontalo is known as one of "local examples" succeeds in performing Islam as the main identity of the cultural building and social development. Adati hula hulaSareati, Sareati hula hula to the Holy Book means Custom based on syara, syara based on the Holy Book (al-Quran) refers to philosophy of Gorontalo people). The legal protection toward women as the violation victims is needed because it is part of the human integrity and nature as the precious creature of God. The principle of Adati hula hulaSareati, Sareati hula hula to the Holy Book referring to Custom based on syara, syara based on the Holy Book (al-Quran) should become legal instrument based on the principle of Developing the national and local law order and also based local wisdom and custom law that becoming the strategic step following the principles of justice, certainty, and benefit as the form of responsibility toward social or governmental mandate in giving legal protection toward women as the victim violence.
\end{abstract}

Keywords: the Principle of Adati hula hulaSareati, Sareati hula hula to the Holy Books, legal protection toward women as the victim of violence.

DOI: $10.7176 / \mathrm{JLPG} / 88-19$

Publication date: August $31^{\text {st }} 2019$

\section{Introduction}

The law protection for Indonesian people resulted from concept and confession of human right values, taken from Pancasila as the ideology and living philosophy giving confession on human prestige and dignity as stated in the Fundamental Constitution of 1945 . Women as one of social power have the same right in participating to fill the independent and change to women development, thus, it should be stated explicitly and specifically to guarantee their right. In the arrangement of several international conventions, the main purpose referred to able to understand deeply on convention in line with women that can be parameter of equality and justice for the women. The arrangement of legal protection toward women was in line with the existence of human right that keeps developing. In Indonesia, the regulation giving legal protection to women right principally has existed however it needed to be optimized. Taken a look deeply, many conditions susceptible happened that women in Indonesia needed protection. The structure of patriarchy society sociocultural placed the men higher than women, even kept aside the women. Moreover, the wrong interpretation of gender may result in universal of women right in Indonesia.

The legal protection for the women as the victim of violence in Gorontalo appeared in building Local Regulation (perda) and activate the law using the principle of "adati hula hula Sareati, Sareati hula hula to Kitabullah " or the Custom Based on Syara, Syara based on Al-Quran referred to form of confession on implementation custom law and local rules of Gorontalo as part of the national law system for keeping the law country and supreme. The principle of " adati hula hula Sareati, Sareati hula hula to Kitabullah " or the Custom Based on Syara, Syara based on Al-Quran called ASQ, besides as philosophy, it also became the identity of Gorontalo that must be obeyed as the ancestral lesson being completed by Islam religion. Because Gorontalo known as one of example area reyang, it used Islam as main identity of cultural building and society development. The local understanding on the principle of "adati hula hula Sareati, Sareati hula hula to Kitabullah" or Custom based on Syara, Syara based on Al-Quran called ASQ referred to custom formula appeared from the Sultan Eato period (1673-1679). This rule considered to be a philosophical fundamental of Gorontalo people life that "cannot be changed".

The principle of "adati hula hula Sareati, Sareati hula hula to Kitabullah " or Custom based on Syara, Syara based on Al Quran or ASQ considered as principle that can give protection toward women as the victim of violence. This principle made the values of Gorontalo keep in original construction, as principle and fundament of formulating and implementing the Local Regulation (Perda) as well as all mandate executors in Gorontalo to give justice, humanity, and prestige for the women.

\section{Research Method}

The research belonged to normative legal research, and the writers tended to study on legal principles, referring 
to study to find out the available legal principles in written or unwritten positive law. The written positive law focused on the Statute of formulating regulation or regulation related, the principles of formulating the regulation, and court decisions related to violation toward the women. This study focused more on philosophical approach, statute approach, conceptual approach, and case approach. The legal material were collected, calculated and analyzed in judicial and qualitative ways by giving priority on legal understanding using legal interpretation.

\section{Discussion}

\subsection{Terminology of the principle adati hula hula Sareati, Sareati hula hula to Kitabullah or Custom based} on Syara, Syara based on Al Quran and its urgency toward the women as the victim violence

The existence of ethic demand to create a good living together by asking consideration on the principle or fundamental of living together. In other words, it searched guidance in thinking and formulating the law in order to be appropriate to the purpose of life and social needs.

In the dictionary of Indonesia, asas (principle) means a truth becoming fundamental or basic of thinking (giving opinion). Whereas in framework of legal norm, asas means something believed its truth and used as principle or fundamental of constructing the legal norms, written and unwritten ones. This principle is not always formulated in provision of a regulation, but its existence is always accepted and become reference of the legal provisions.

The general legal principles vary, depended on the meaning of fundamental law, followed by the writers. Paul Scholten in his paper, Rechtsbeginselen, stated that legal principles referred to "tendencies that required for legal by our norm understanding" (tendenzen, welke ons zedelijk oordeel aan het recht stelt). Karl Larenz gave his similar opinion to Paul Scholten that legal principles referred to parameters give guidance to legal construction.

The function of legal principle covered four (4) parts namely: 1) Legal principle means guidance for law maker; 2) Legal principle helps to detail the interpretation; 3) The legal principle help related to analogy; 4) The legal principle helps to give correction toward regulation threated losing its meaning.

The philosophy of adati hula hula Sareati, Sareati hula hula to Kitabullah or Custom based on Syara, Syara based on Al Quran or ASQ means starting point of a long line in development of custom society in Gorontalo. Big seminar of Gorontalo custom conducted in 1971 not only resulted in an important historical document but also became a literature milestone and achievement of Gorontalo local civilization giving working paper on "The History of Custom and Islam" transparently formulating the saying "Adat bersendi syara, syara bersendi kitabullah (Quruani)" called ASQ. ASQ was "never written", but it referred to demand that must be obey as ancestor law being completed by Islamic Religion, mainly, on how the main elements in "universe" (wind, fire, water and land) and completed by human element (norm, willing and life).

The formula of "adati hulahulaa to saraa, saraa hulahulaa to Quruani" referred to a custom formula born in the time of Sultan Eato (1673-1679). This regulation might be called a philosophical fundamental of the social life in Gorontalo that "cannot be changed according to tuja'i-tuja'I cited from classical literature in M. Lipoeto (1945, Chapter VI: 23, 24). An interesting conclusion would be the Arabic letter had been used in Gorontalo since 1525 after the kings of raja-raja Tamalate, Lemboo, Siendeng, Hulangato, Sipayo, Bunuyo, Soginti and Siduan arrived in Gorontalo, exactly in the area of Hunto, and in this place the first mosque built. However, the several years following, in 1563 Islam truly became the official religion of the kingdom and society. The arrival of the kings happened several days before Maulid of Prophet Muhammad SAW 932 Hijriyah, around 1525 Masehi. The achievement making Islam to be the official religion for the kingdom and people became result of the Matolodulakiki period (1550-1585).

The custom of Gorontalo was described "the custom of Gorontalo based on natural laws referred to bless for the Gorontalo ancestor from the Only God...The arrival of Islam to Gorontalo became new blessing for Gorontalo people with directly get guidance from the God through the holy book of Al-Quran brought by the Prophet Muhammad SAW ....Thus, Islam with its arrival in Gorontalo did not destroy the custom of Gorontalo, such as Islam destroyed other beliefs, but arrival of Islam meant completed the Gorontalo custom... Therefore, it was not surprised, for the truly people and society of Gorontalo and the developing nature became the teacher. The nature was blessing from Allah SWT for the ancestor to be used for him with purpose to leave good things and given away to the future generation".

In line with the principle of "adati hula hula Sareati, Sareati hula hula to Kitabullah" or Custom based on Syara, Syara based on Al Quran called ASQ, it should be principle, fundamental, and parameter in thinking and behaving of Gorontalo society. Because this principle close related to main identity of cultural building and society development of Gorontalo known as one of example area succeed in making Islam as its main identity.

It also along with legal principles known in 3 kinds, covering: 1) the principles of moral classical objective law. These principles have existed in the classical mid-century philosopher; 2) the principles of rational objective legal including rational principles of legal understanding and living together rules. They also had been accepted 
longtime ago, however, they just revealed factually since modern era, when appearance of the national and legal made by Yuris people professionally; 3) the principle of moral or rational subjective law, that the right $s$ of human being and parameter of constructing the law. The development of law appeared clearly in this field.

The principle of adati hula hula Sareati, Sareati hula hula to Kitabullah " or Custom based on Syara, Syara based on Al Quran, must become proper legal norm hopefully not only giving legal protection toward the women as the victim of violence, with preventive purpose, but also in repressive, meaning conduct handling and punishing the doer or legal breaker. Based on the principle, the people of Gorontalo have cultural values and belief being honored, believed, and hopefully giving legal protection. Because the law understood as the principle of naturally considered as human will to achieve a structure of together living appropriate to the moral and legal norms as ethics co-existence. Human as the God creature has existence subject concretely can give justice, certainty, benefit as the law purpose. Because the law was part of human effort to create a co-existence ethic in the world such as Asas adati hula hula Sareati, Sareati hula hula to Kitabullah " or Custom based on Syara, Syara based on Al Quran as the moral norm requiring each person to mentally and materially arrange the living together in its implementation decided the right and responsibility as legal norm in giving protection toward the women as the victim of violence.

\subsection{Legal Protection on The Women as The Victim of Violence}

The convention of CEDAW referred to the international Human Right Instrument embedding legally and belonged to convention ratified by many countries. This convention was single international instrument formulated in specific way to increase and protect the women rights and considered as Bill of rights for women (Indonesia has participated in this process).

The convention placed the women rights in Gender problem becoming the core and central of the theory and practice of Human Right. The Fundamental Convention of CEDAW was similarity or equality of men and women guarantying not only equality decided formally in legal regulation ( formal equality or de jure), but also de facto equality, and substantively, meaning the real equality and the result can be obtained in real way.

Thus, the principle of adati hula hula Sareati, Sareati hula hula to Kitabullah " or Custom based on Syara, Syara based on Al Quran in Gorontalo in protecting legal toward women as violation victim as guide or living base of creating legal norm morally and rationally. Women have right embedding in line with reality of human life and available right result from regulation based on the law.

The form of legal protection toward women as the violation victim in Gorontalo was by providing comprehensive Local regulation with starting point on the women experience substantively covered three (3) things:

1. Place women experience in substance of Local regulation with women right perspective

The problems of violation against women rights, women suffering that underestimate her dignity and prestige so far unknown, understood and reflected by the regulation, or on judge decisions, or been minimalized because not enough expressed in the law. The women experience before and after becoming a victim must obtain significant priority and may not be ignored because it became value of a woman having different condition and experience when faced the situation and condition as victim.

2. Construct legal structure as form of existence of Human right institution as the effort to uphold Human

Right in Indonesia

The institution of Human right was constructed to accommodate the women experiences, identify the rights being struggled and constructed concrete strategy that able to develop, protect and eliminate actions that against the women right in purpose to transform the living condition that respect women right. Women body and honor related to human life value or living dignity and prestige accepted in The Universal Declaration of Human Rights (10 December 1948). Thus, justice and truth becoming symbol of humanity that can be felt and used by women with such condition.

3. Develop legal culture accommodating the women interests

According to Maggie Human feminism fighter for humanity and women as human completely where principally placing the women position as complete subject in making the decision applied for all women in anytime and place. The legal opinion using feminism perspective appeared from fundamental assumption on the relation of women and law. The feminist and feminist law practitioners stated that women perspective is different from men perspective. Thus, it needed law based on norm and women experience to achieve renewal and legal recovery in the future.

It was in line with keeping the principle of adati hula hula Sareati, Sareati hula hula to Kitabullah " or Custom based on Syara, Syara based on Al Quran, as the starting point of legal construction related to the meaning of human life as the principle of legal morality that stating:

1. Anyone having belief would agree that we needed to giving aspiration for the custom society living structure, political life and good judicial, especially in supporting justice of life. Thus, religion became living fundamental. The law must be made appropriate with available values 
related to sense of human morality and religion rules.

2. In constructing the legislation and do mandate, it needs consideration that must be considered that healthy religion may guide goodness to find out the proper principle.

Thus, the principle of adati hula hula Sareati, Sareati hula hula to Kitabullah " or Custom based on Syara, Syara based on Al Quran in Gorontalo in protecting legal toward women as violation victim as guide or living base of creating legal norm morally and rationally. Women have right embedding in line with reality of human life and available right result from regulation based on the law.

\section{Summary}

The principle of "adati hula hula Sareati, Sareati hula hula to Kitabullah" or Custom based on Syara, Syara based on Al Quran, must become properly legal norm as the legal instrument based on the principle of developing the national and local legal structure with local wisdom and custom law as its base. It referred to strategic step based on principles of justice, certainty, and benefit as form of responsibility on the social or governmental mandate in giving preventive or repressive protection by handling and punishing the actors or legal breakers. Thus, the law understood as principle of human will to create a social structure based on morality norms as an ethic co-existence. The principle of yang "adati hula hula Sareati, Sareati hula hula to Kitabullah" or Custom based on Syara, Syara based on Al Quran referred to moral norm requiring each people materially and morally to arrange his social life in its implementation deciding the right and duty as legal norm in giving protection on the women as violation victim.

\section{Reference}

Achier Sudiarti Luhulima, 2014, CEDAW Menegakkan Hak Asasi Perempuan, Jakarta, Yayasan Pustaka Obor Indonesia

Archie Sudiarti Luhulima, 2006, Perempuan dan Hukum, Menuju Hukum yang berperspektif kesetaraan dan keadilan, Jakarta, Yayasan Obor Indonesia

Ahmad Nur Fuad, dkk, 2010, Hak Asasi Manusia dalam Prespektif Islam, Malang, Madani

Baharuddin Lopa, 1996, Al-Qur'an dan Hak-Hak Asasi Manusia, Yogyakarta, Dana Bhakti Prima Yasa

Buku HAM Pusat Studi Hak Asasi Manusia Universitas Islam Indonesia, 2008, (PUSHAM UII), Yogyakarta

Basri Amin, Islam, Budaya dan Lokalitas Gorontalo, Google Schoolar, Universitas Negeri Gorontalo

Darji Darmodiharjo dan Sidharta, 1996, Pokok-pokok Filsafat hukum, Apa dan Bagaimana Filsafat Hukum Indonesia, Jakarta, Gramedia Pustaka Utama

Frank E Hagan, 2013, Pengantar Kriminologi; Teori, Metode, dan Perilaku Kriminal, Jakarta, Prenadamedia Group

H.L.A. Hart, Konsep Hukum, 2011, Terjemahan . M. Nasihan dkk, Jakarta, Cyntia Press,

J.E Sahetapy, Modernisasi dan Viktimologi, 1987, Sinar Harapan, Jakarta

Lusiana Margareth Tijow, 2017, Perlindungan Hukum Terhadap Integritas Tubuh Perempuan Korban Tidak Dipenuhinya janji Kawin Dalam Perspektif Hak Asasi Manusia, Malang, Disertasi, Universitas Brawijaya

Moerti Hadiati Soeroso, 2010, Kekerasan Dalam Rumah Tangga Dalam Perspektif Yuridis Viktimologis, , Jakarta, Sinar Grafika

Mufidah Ch, 2008, Pshikoogi Islam Berwawasan Gender, Malang, UIN-MalangPress

Murthadlo Muthahari, 1995, Hak-hak wanita dalam islam, Lentera Jakarta, cet. 3

Niken Savitri, 2008, HAM Perempuan Kritik Teori Hukum Feminis;Terhadap KUHP, Bandung, Revika Aditama

Theo Huijbers, 1995, Filsafat Hukum, Yogyakarta, Kanisius 